\title{
Communication Approach in Teaching English as a Foreign Language: In reference to Uttar Pradesh
}

\author{
Dr. Reena Mittal \\ M.A. (Eng.), Ph.D., M.B.A Reader and Head Department of English DAK Degree College Moradabad,
}

\begin{abstract}
The present paper is a study of the condition of Englishin Uttar Pradesh as it is considered to be worst of all the states of India. It also suggests ways of teaching English in Uttar Pradesh and Introduction of Communicative Language Teaching can be really vital. English is considered to be a mandatory skill of survival in the present circumstances but irony is that Government is not giving so much consideration to this fact. The paper suggest some remedy for the improvement of standard of English in UP as writer observes many drastic mistakes and problems of undergraduate students personally. The paper is an attempt to draw attention towards those problems and find a solace.
\end{abstract}

Keywords: Communicative, multilingual, skills, undergraduate, Fluency.

\section{Introduction}

English language presently can be called the blood running in the veins of the human being. It is the burning necessity to have fluent English speaking skill if modern youth want to progress. The increasing graph of popularity of English really make English teacher more responsible. Teaching English to non-natives is not an easy task because regionalism in pronunciation remains active this or that way. In this regard many study and survey were made to know the short comings of fluency among non-natives. Then CBSE introduced a new trend known as CLT (Communication Language Teaching) to implement and rectify errors of speaking and communication. This new trend although not implemented in many schools even of UP, but giving good results wherever it is existing.

\section{English in India}

India is a multilingual country with nearly every third person is bilingual. We have so many languages to speak and people believe in speaking their Mother Tongue or Native Language. They are aware of use of English, very fond of learning and using English still they are not aware of many skills and intricacies of English language learning. Although English is considered as a foreign language still in India and its states,yet policy makers and country men have understood the need of English in political, cultural, social, professional, business, economic aspects of life. To understand technology and science is to understand English. Hence English in India became first official language at it is working as connecting diversified India.

\section{CLT and India}

CLT is one of the best solutions to all the problems of English learning. To whomsoever country, the first language is not English, they applied and get fruitful results with the help of CLT. With the advent of globalization, CLT has become a fruitful necessity. When we compare it with ELT, we find that aristocracy of ELT is erased and cut to reality with the help of implementation of CLT. Use of cross cultural literature has opened new openings of understanding, reading of different cultures. Many non-English speaking countries like China, Korea, Pakistan and others surveyed and then realized that CLT can give new dimension to English teaching. In China, it was not easy to teach traditional English Grammar. But use and implementation of Communicative English has given innovative successful results. The greatest barrier in applying CLT in the course structure is:

- Issues of Teachers - Teachers also lack fluency of speaking; their work load and large no of students always work as a barrier in applying CLT. Teachers have no or less opportunities to update themselves.

- Issues of Students - Students fluency, hesitation in speaking, pronunciation problems is again an issue. Large no. of students in classroom again is a barrier for teachers and students both as they can't communicate one to one.

- Education Policy and its limitations - Our education policy changes with the speed of a tortoise. This creates a great hindrance. As policy makes have to be flexible and result oriented while they make rules and policies. In many universities of US and UK, course structure is so flexible that they read and learn most new inventions. It has to be like this in our country too. 


\section{Some practically faced Issues}

Students with good communication skills and fluent English speaking can place themselves and explore new height of success. Many students in UP lack in communication skill, they are enthusiastic about selection of English as a subject in undergraduate level but they can't speak or write correctly. I have noticed that student coming for admission can't even write a basic application in English. They are over enthusiastic in selecting General English and English literature both as it increase their matrimony value but unable to speak 'Literature' properly. ' $R$ ' becomes ' $L$ ' for them. They secure good marks in +2 examination but their spelling and construction mistakes make the atmosphere of the class miserable sometimes. I am working in an undergraduate girl's institution where all students prefer taking English but their level at +2 was really pathetic. They can't give their introduction in English; answers of classroom study are always hard nut to crack.

\section{CLT a balm and boon}

So, implementation of CLT at +2 levels can bring a new era in English teaching for non-natives. The best communicative skills can be developed with its help. Although the application of CLT can be at any level but secondary level can produce best of results.

Communicative language teaching came into existence in late 1970s and Europe started practising it especially at school and +2 levels. Its main origin was to influence teaching methodology and make language teaching interactive among teacher and student. Students participate enthusiastically and many constrain such as speaking hesitation, pronunciation error is removed very easily. CLT make use of real life situation with the help of communication. The teacher is supposed to create a situation in which every student has to answer which is the foremost function of the language. The main Elements of CLT are:-

- Communication as per Talent

- Accuracy and Fluency

- Continuous learning process

- Motivation among students

These elements are compulsorily required when learning a language. As per need, language gives us expression to show our feelings, emotions, talent and expertise to others. Students normally pass their examination by cramming their syllabus but unable to express themselves even in few sentences.

So, CLT worked well in this regard. Normally curriculum provided in CLT is task based. Teachers create situation, give outline of events and task to students, they in return give answers verbally, suggestions and try to solve the problem. All this hone their ability to communicate as it is observed that students hesitate in speaking.

Margis S. Berns, an expert in the field of CLT, writes in explaining his views,

"Language is interaction; it is interpersonal activity and has a clear relationship with society. In this light, language study has to look at the use of language in context, both its linguistic context and its social, or situational, context (who is speaking, what their social roles are, why they have come together to speak)".

\section{Conclusion}

Thus we can conclude by saying that Uttar Pradesh is a state where MT or first language is Hindi or other shades like Bhojpuri, Awadhi, Banarasi, of Hindi are so prominently present that English and its pronunciation and fluency is checked. Students want to go for English learning and speaking like Native speakers but their background forbade them to speak. They hesitate in flawless and fluent speaking. So, CLT seems to be boon in this respect. But to implement it at +2 level means to educate or trained teachers for this. One major problem is large no of classes which also restrict teacher's one to one interaction with students. But the kind of quality teaching CLT can provide seems to be a rescue of raising standard of English in Uttar Pradesh.

\section{References}

[1]. www.wikipedia.com

[2]. Berns, M.S. (1984). Functional approaches to language and language teaching: Another look. In S. Savignon \& M.S. Berns (Eds.), Initiatives in communicative language teaching. A book of readings (pp. 3-21). Reading, PA: Addison-Wesley.

[3]. Gerngross,G., \& Puchta, H. (1984). Beyond notions and functions: Language teaching or the art of letting go. In S. Savignon \& M.S. Bern's (Eds.) Initiatives in communicative language teaching. A book of readings (pp. 89-107).

[4]. Reading, PA: Addison-Wesley.

[5]. Larsen-Freeman, D. (1986). Techniques and principles in language teaching. Oxford University Press.

[6]. Littlewood, W. (1981). Language teaching, An introduction, Cambridge: Cambridge University Press.

[7]. Savignon, S., \& Berns, M. S. (Eds.), (1984). Initiatives in communicative language teaching. Reading, PA: Addison-Wesley.

[8]. Www.onestopenglish.com

[9]. www.wikipedia.com

[10]. Journals of IATEFL. 